\title{
The Quiet Violence of Rape: Unnamed Survivors, Unnameable Scars
}

\author{
Khaya Gqibitole \\ University of Zululand, Empangeni, South Africa \\ Email:kgqibit@yahoo.com
}

How to cite this paper: Gqibitole, K. (2020). The Quiet Violence of Rape: Unnamed Survivors, Unnameable Scars. Open Journal of Social Sciences, 8, 86-104. https://doi.org/10.4236/jss.2020.88007

Received: January 27, 2020

Accepted: August 11, 2020

Published: August 14, 2020

Copyright $\odot 2020$ by author(s) and Scientific Research Publishing Inc. This work is licensed under the Creative Commons Attribution International License (CC BY 4.0).

http://creativecommons.org/licenses/by/4.0/

\begin{abstract}
Rape narratives have often focused on race. Unfortunately, the long term psychological damage survivors suffer is often disregarded or not treated seriously. Even reported cases are sometimes removed from the court roll without the knowledge of the survivors. The present study aims to highlight the lifelong impact of rape on the survivors by analysing literary texts that feature rape both in South Africa and elsewhere. Rape is often gendered; however, I argue that ascribing rape to women only is patently abysmal because men are too victimized. The permanent psychological damage caused by rape is often understated; therefore rapists may be aware only of the physical pain they inflict. Rape is a crime of power, which is informed by patriarchy, hate, a sense of entitlement, a penchant for body control, a "threatened" masculinity and a herd mentality. The violation often results in desperate actions such as suicide, homicide, self-blame, and identity-confusion. Silence remains the most conspicuous and disturbing commonality among the survivors; hence the paper uses Noelle-Neumann's (1974: p. 43) spiral of silence theory to understand the survivors' silence. Some of the prevailing reasons for silence are economic dependence, cultural dictates, immaturity, fear of social isolation, as well as the inattentive legal system. It is critical to note that rape cuts across time, space, culture, gender, race and class. It is a global phenomenon; hence I examine rape in three geographically disparate novels; Aidoo's Changes (Ghana), Angelou's I know Why the Caged Bird Sings (USA) and Duiker's The Quiet Violence of Dreams (South Africa) as well as other textual accounts in order to elucidate the impact of rape on survivors. Finally, I argue that programs developed to deal with the scourge should be based on credible and reliable analysis of the rape pandemic.
\end{abstract}

\section{Keywords}

Rape, Silence, Instrumental Aggression, Hostility-Driven Aggression, Psychological Damage 


\section{Introduction: The Problem}

Even though rape has been the subject of literature throughout history; more in-depth, nuanced and up-to-date research still needs to be conducted, firstly on why people rape (as opposed to the standard question, "why do men rape?"), secondly on the would-be-rapists' understanding of what survivors of rape go through and, thirdly and more importantly on the life-long ramifications of rape on the survivors. Studies on the subject have often reduced rape to the politics of race and gender, thereby overlooking the different degrees and the complexities of the violation on the survivors. While McKibbin et al.'s (2008: p. 86) description of rape as the use of force or threat of force to achieve penile-vaginal penetration of a woman without her consent is acceptable, it is rather limited since it excludes male rape and other aspects consistent with the defilement. Clifford's (2008) take, on the other hand, that "rape is forced vaginal, anal, or oral sex, of either male or female with either a person or an object, including the force used by a person to rape or sexually violate another person of the same or opposite sex", is far more accurate. Rape dehumanizes and leaves deep scars on the survivors. Frequently though, survivors suffer in silence instead of reporting their experiences. Rape is not only intrusive but it is also a serious violation of an individual's human dignity and person. Its degradation is total and final, as such cannot be inverted no matter what intervention is contemplated. Rape neither recognises class and race, nor respects geographic boundaries. Reference to South Africa, while it is regarded as the capital of rape in the world, is only used here as a springboard to discuss the devastation rape causes to individuals, families, communities and nations. According to du Toit (2014: p. 101-102) rape in South Africa surpasses that of any country at war. For instance, annually 65,000 rapes have been filed with the South African Police Service, and the number continues rising. In 1999, the South African Law Reform Commission rape estimate was 1.6 million cases. The paper suggests that, in order to curtail rape incidents a more globalised approach is necessary to achieve this; pre-emptive, progressive and effective programs targeted to the prospective rapist should be developed. Understanding and having insight into the impact of rape on another human being may serve as a timely deterrent to would-be rapists.

The silence that accompanies rape is awkward and is often misunderstood as intransigence as it happens to Marguerite in Angelou's I Know Why the Caged Bird Sings, or more cynically as the survivors' complicity in the act. However, survivors' silence may be a sign of an existential crisis from which they cannot redeem themselves. This society-induced silence has far-reaching consequences such as homicide or social isolation. The German philosopher, Noelle-Neumann, refers to this as the "spiral of silence" where the weight of public opinion overwhelms the survivors. Fear of stigmatization and physical harm often compel survivors to die with the pain than inviting the ire of the society. This paper uses Noelle-Neumann's notion to expose the difficulty survivors have in speaking up of their ordeal. Victims need support systems to help them deal with their plight. 
At times, though, it is the self-same confidants who exacerbate their predicament by either keeping silent or silencing the survivors. The silence can be occasioned by parents who want to avoid embarrassment and protect family honor, police who treat rape as falsehood, courts which have other "pressing" cases to deal with and friends who have another strawman to attack.

\section{Research Approach}

The paper uses a qualitative approach to analyze literary texts and scholarly journals that deal with rape. The paper uses novels from different regions and countries to highlight the commonalities in the way survivors respond to rape. While race, place and class are critical discussion points of rape, the impact of rape on the survivors is equally important. Although to a lesser degree, quantitative approach will be deployed to furnish statistical evidence of rape. In this regard, statistics from entities such as the police reports, health ministry reports and Statistics South Africa and the South African Law Reform Commission will be used. The study uses Noelle-Neumann's (1974: p. 43) spiral of silence theory to help us understand the silence of the survivors of rape. As she puts it, " $[t] o$ the individual, not isolating himself is more important than his own judgement". Based on this view, I argue that survivors of rape opt for silence to avoid stigmatization, physical harm and ostracism. On the other hand, I will argue that the society engages in a conspiracy of silence through its social expectations for members of the community to conform to the accepted prescripts of the group at large. Hence, incidents of rape are sometimes referred to tribal courts (iinkundla) or families to deliberate on instead of taking the legal route.

\section{Blood on the Page: Some Literary Accounts}

Women are often presented as the primary targets of rape because, as Walker et al. (2005: p. 70) argue, "most victimological research on the effects of post-rape trauma has focused on female survivors". There are numerous motivations for rape and the violations happen in specific social context that may give one insight into the perpetrator. In this regard, Jewkes et al. (2010: p. 29) make an important observation when they point out that "rape is seen, at times, as an appropriate means of expression of gender power among men who have fantasies of status and power, but who lack sufficient education or earning ability to be able to enjoy most of the benefits of a higher social position". Thornhill \& Craig (2000: p. 4) make a similar point when she argues that "men might resort to rape when they are socially disenfranchised, and thus unable to gain access to women through looks, wealth or status". The popular view that rape is anger-driven (with heavy political rhetoric sometimes) is both misleading and a narrow way of looking at rape since it disregards men's in-born desire for sex. Thus, McKibbin et al.' (2008: p. 89), identification of five types of rapists debunks the anger view. The five types they identify are; 1) partner rapists motivated by assessment of increased risk of sperm competition, 2) men who rape opportunistically, 3) 
"specialized" rapists who are sexually aroused by violent sex, 4) disadvantaged men who resort to rape and 5) high-mating-effort men who are dominant and often psychotic. This paper confines itself to three types 1), 2) and 3) as they obtain in the texts dealt with below.

Countries that have been colonised often have high incidents of rape which were initially normalized by the colonisers. A good example is South Africa which is often regarded as rape-prone today. Rape narratives abounded during the colonial era, although official records and reports distorted the picture to favour the powerful, the connected and the super race. The subsequent system of apartheid worsened the situation when relations between blacks and whites worsened due to the institutionalization of racism. As is the case in oppressive regimes, rape was used as a tool to subdue, humiliate and annihilate black people. The brazenness of the violations clearly exposed the impunity and protection the individuals enjoyed. Govinden (2013) makes a similar point when she says, "in fact, rape was a major but hidden social problem under apartheid". State power, as it is aptly demonstrated in Minnie and Steyn's (2018) The Lost Boys of Bird Island, insulated some senior officials who debased young boys on a secluded island off Port Elizabeth, South Africa. Rape was not only used as a tool of suppression; it was also used to regulate the white minority and sow fear and suspicion in the country, hence the "black peril" and "white peril" parlance that gained currency in the apartheid years.

"Black peril", generally referred to as "swart gevaar" in South Africa, was a ploy by the then apartheid government to rule by fear. In this regard, the white male dominated government indoctrinated whites to believe that black men were out to rape white women. Such pronouncements pervaded every nook and cranny of the country and deepened the tensions between blacks and whites that still prevail today. Using race as a scare tactic is not a sole preserve of South Africa, though. McCulloch's (2000) book, Black Peril, White Virtue, deals with this at length in the then Southern Rhodesia. Stripped of its political rhetoric though, the ghastliness of black men raping white women has been documented. Coetzee's Disgrace (2000) perhaps best illustrates this hideousness although his seeming subjective exposition of the incident may be questionable. Coetzee's use of rape to address bigger socio-political issues speaks to the entrenched racialization of rape in the country. In the novel, Lucy, the survivor, neither reports the rape nor does she readily tells her father, David Lurie, what transpired between her and her attackers. She grudgingly holds on to the memory as she tries to understand why her violators hated her so much. What she decodes from the incident drives a wedge between her and her rather old-fashioned but educated father because she realizes the sacrifices white South Africans have to make to right the wrongs of the past. David Lurie, on the other hand, cannot believe when his daughter seems to accept the gang rape as an instance that would forge reconciliation and coexistence between blacks and whites. Unlike other white women, she refuses to take the well-travelled road of the paranoia and instead 
attempts to be forward looking. She is keenly aware of the paranoia of her father's generation, as Govinden (2013) argues, a generation which is eternally averse to "miscegenation" (used pejoratively) and based on the desperate need for the preservation of (a questionable) racial purity. She understands the debilitating indoctrination her father's generation were subjected to.

David, meanwhile, is caught between his unyielding love for his daughter, his innate but guarded suspicion of blacks, and his keen understanding of what pure desire for a woman can do to a man. Challenged by Melanie's boyfriend, Ryan, to leave Melanie alone, David muses: What does he (Ryan) know of the force that drives the utmost strangers into each other's arms, making them kin, kind, beyond all prudence? His rationalization of his own excesses exposes the normalized violation of black women in the country. Even though he secretly sees himself in his daughter's violators and identifies with them, he does not regard his own defilement of Melanie, a young coloured student in his class, as absurd and as evil as what happens to Lucy. It is for this reason that he refuses to admit to any wrong-doing to the disciplinary committee at his university. Even his apology to Melanie's parents later on is not genuine but is just a ploy to rid himself of any lingering association with Lucy's violators. Fashioning his own abuse as "not real rape" camouflages it as a sincere relationship.

David Lurie's rape of Melanie, though, is a reflection of a well-guarded secret both in the colonial and apartheid eras. There is evidence, as Govinden notes, that the "white peril" narratives were often used to counter black peril narratives as black authors tried to protect and reimagine black identity. Rape, as suggested above, is a great-leveller since it occurs across race and class. Mda's (2002) The Madonna of Excelsior, best captures and elucidates the sexual violence oppressed black women suffer and their vulnerability to white lust. In many instances the rape of black women was swept under the carpet to save the honour of the Afrikaners which Henning variously calls ordentlikheid (decency) (van der Westhuizen, 2017). The unstinting impunity did not only exacerbate the rape of black women, but it also exposed partiality of the legal system. The Immorality Act, for instance, was only used against blacks even when the perpetrator happens to be white. The official line was clear, the face of rape is black and white women are victims thereof. No matter how black authors tried to counter that narrative by exposing "white peril", the apartheid machinery was tuned to suppress any notion of white rape even in instances the violator was obvious.

\section{Redeeming the Aggressor?}

Rape kills the survivor from the inside but the voices that are often heard are those who uphold the rights of the perpetrator both in courts of law and in traditional iinkundla (traditional settings where justice is dispensed). In such spaces rape is gendered, as such the rape of women is often dismissed as a domestic matter, while the rape of men is often shunned. The increasing rape of men is equally devastating and widespread even though it is less reported. Characteris- 
ing rape as a female problem informs the deafening silence of male survivors out of concern of being isolated and further victimized. The repercussions for both genders are equally devastating, but corrective rapes are often more brutal. This excessive violence may be indicative of a threatened masculinity or masculinity in crisis where the rapist sees the lesbian as undermining and challenging his manhood. His is to correct the anomaly, and as such render a service to the community. The silence of the said community to condemn such conduct only gives the perpetrator a falls sense of righteousness which leads to the normalization of the "othering" of gays and lesbians. As demonstrated in The Quiet Violence of Dreams, male rape has dire consequences because the society often lynches the survivor and treats him as a persona non grata. More often than not, the perpetrator(s) is secretly hailed as a hero for saving the society from the "madness" of homosexuality, hence convictions for those who perpetrate the rape of lesbians and gay men is far too low. In the domestic sphere rape is far more normalized, especially as it pertains to domestic workers.

White households in South Africa predominantly hire black women as domestic workers. The life of the domestic worker is a subject of many books by black authors mainly because of her double stratification as being black and female. Mphahlele's Mrs Plum is pehaps a good example of this. Her skin colour and gender place her in a preeminent position to be an easy target mainly because of the secluded nature of her workplace and, unfortunately, the complicity of the white madam who decides to looks the other way than to bring shame to the volk by exposing her husband. As Bloke Modisane laments in Blame Me on History, the law is white in South Africa. Modisane's observation is demonstrated in Mda's The Madonna of Excelsior where the white perpetrators of the heinous rape crimes are absolved of any crime just because they express their embarrassment for procreating with black women. The men do not own up to their crimes as though they are entitled to having sex with the domestic workers; as long as they do not make children with them. This echoes Lurie's concern after Lucy is raped by black men. Even their crimes against the hateful Immorality Act are expunged to save the Afrikaners' good name, while the black women they violated spend jail time ostensible for "breaking" the same law by sleeping with white men. The stigma of "sleeping" with their bosses and the criminality that accompanies it follows them to their unforgiving communities.

Rape is not just a physical exercise, it invades and destroys souls. The resultant pregnancies of the rapes destroy families and communities. These women do not only have the burden of raising mixed-race children, but they are also expected to love and care for the reminders of their humiliation. Their "in-between" children serve as a reminder that is perpetually etched in their hearts and minds and communities. As Caryl (2017) argues, "by creating shame and humiliation it destroys ties with families and communities. It silences and paralyses". In The Madonna of Excelsior, for an example, a rape survivor, Niki, in desperation tries to Africanise her "in-between" child by cutting his hair and exposing him to the 
fire to darken his skin-a futile act to expunge the guilt and shame she feels. While these desperate measures may seem unworkable and extreme at face value, they nonetheless reflect the psychological damage such women suffer long after the violation. Women and their children are perpetually marked as deviants who should be shunned by the whole society, a burden that would be besmirch their bloodline to perpetuity while their violators live large.

White males are not the only beneficiaries of the apartheid system; black males too continue to benefit. The anger of the black man in such circumstances is wholly understandable, but to claim that they rape because of the deep-seated anger caused by apartheid is suspicious and fallacious. This is a belief that must be disavowed by those in top echelons of government because it has the potential to justify their transgression towards women. Such a false narrative may inadvertently give licence to black man to rape with impunity, in the same way white men were during apartheid. Instead of blaming the past, treating the body of a woman as a commodity must be demystified. Her body has been a battle field for men for far too long to continue unabated in the name of past political trauma. This is true of married women whose husbands believe they are entitled to have sex with them. This fallacy is aptly demonstrated in Aidoo's Changes. In Changes, it is clear that men are simply driven by sexual gratification and the overarching patriarchy. Rape cannot be easily explained away as anger against the colonial and apartheid masters or what du Toit (2014: p. 102) calls "past-perpetrator-trauma". Rape, men must learn, cannot assuage feelings of inadequacy, insecurity, humiliation, poverty, hunger and want. Rape is a criminal act that cannot be justifiable. It is self-serving because the perpetrator derives pleasure and gain a sense of power from it. This explains the attendant brutality which is occasioned by the survivor's suffering which the violator mistakes for power. A point maintained by Hamilton \& Yeew (1990: p. 119) who say that, "angered subjects are stimulated to further aggression by the perception of their victim's suffering". Mckibbin et al. (2008: p. 89) categorise such perpetrators as "specialized" rapists who are sexually aroused by violent sex.

The recent spate of rapes in South Africa has sparked heated discussions about the possible causes of the spike. Anger, as suggested above, is often singled out as the main cause because of the brutality at display. However, I slightly disagree with Hamilton and Mckibbin and argue that the brutality in itself doesn't denote anger and desire to physically hurt, especially if the rapist is known to the survivor. du Toit (2014: p. 101) notes that a 2009 study revealed that 84 percent child victims and 52 percent adult victims were known to the perpetrator. Being acquainted to the survivor perhaps explains the attendant ferocity as the perpetrator uses violence to silence the former who may report him to authorities. I concur with Thornhill \& Craig (2000: p. 4) that "even in those few cases in which rapists use brutal force, it may be that the murder takes place not because the rapist is motivated by a desire to kill, but because by removing the only witness to the crime he greatly increases his chance of escaping punishment". Whatever 
the motive, though, the survivor pays the supreme price. If she survives, deep psychological scars remain but because of the conspiracy of silence around rape, many of the cases are underreported and as such unaccounted for. I, therefore, maintain that rapists mainly violate for sexual aggrandisement or what Hamilton \& Yeew (1990: p. 119) refer to as "instrumental aggression" since the main motivation seems to be sex and not necessarily maiming or killing. Hamilton reasons that the rapist wants to have sex with a woman and obtains this by force. Most commonly, Jewkes et al. (2010: p. 27) add, rape had been perpetuated out of a sense of sexual entitlement. Women's bodies, and indeed the feminised body of gay men, are battlefields for men. I concur with du Toit (2014: p. 102) when he says "male rape victims are typically feminised in and through rape by men who identify as heterosexual". Rape thus is a highly gendered crime . Rape is not only gendered; it also defies class as the violations by politicians during apartheid demonstrate.

\section{The Politics of Rape and Conquest}

South Africa has not yet emerged from the long shadow of its violent past, considering the flare-ups of racial skirmishes occasioned in part by the binary of poor/rich, black/white, landless/landed. Claiming that the country is still an active (if low-scale) conflict zone, therefore, wouldn't be far-fetched. Graham (in Govinden, 2013) views this differently when he "notes that in literature the emphasis has largely been on inter-racial rape, and to an obsessive degree". We tend, she adds, to forget that, in fact, South Africa is the scene of more intra-racial violations, tantamount to a prolonged civil war. Despite certain individuals' expressed doubt that there is direct correlation between the colonial and apartheid past and the rape culture that bedevils the country, the opposite is true. While I argue that anger as occasioned by apartheid cannot justify the rape we witness currently, that the system of apartheid normalized the rape of the oppressed cannot be denied. Rapes committed by the all-powerful often reflect the racialized nature of the society. As pointed out earlier, oppressive governments sometimes use rape to permanently dehumanize communities and break them down. Countries such as Syria, Sri Lanka, South Sudan, DRC, Rwanda and Bosnia come to mind. Once the moral core of the society is destroyed, misdemeanours perpetrated by the elite such as rape are likely to become common place. As Caryl (2017) points out, [t]hese stories (of rape) are about power than they are about sex. Specifically, for one in position of power, it's often about demonstrating the extent of their control over the vulnerable. In mainstream media though such abuses are sometimes kept under wraps, while civilian rapes make the headlines because one of the first casualties of rogue governments is the media. Once the media is state-controlled impunity pervades all levels of governance. State power is often used to protect the perpetrators, while dismissing the experiences of the survivor. Colonel Tint of Burma's utterances, perhaps, sum up the attitude of the elite. Caryl (2017) quotes him as having said, "Look at 
these women who are making these claims-would anyone want to rape them?". As alluded to above, research shows mostly women bear the brunt of rape. Clifford (2008) points out that, "rape as a weapon of war affects not only the survivor, but place all women and girls in fear of sexual violence. Fear dominates the daily life of all women and girls who are living in a conflict zone. This continual fear leaves survivors in constant torment and mental anguish, which causes increased long-term psychological stress and damage". The purpose of the rapes, Caryl (2017) avers, is clear. The aggressor aims to impose the most extreme humiliation on his victims, to destroy their dignity, to devastate souls. This isn't about pleasure. It's about the calculated and vicious exercise of power over a helpless target.

As alluded to earlier, while it is women who are mostly violated, the whole community is directly affected. This break down of the society can be seen in notoriously volatile countries such as the Congo where child soldiers are initiated to rape at a young age; where women are detained as sex slaves. According to Clifford (2008), "research states that rape as weapon of war has now 'metastasized into wider social phenomenon', which now reaches further than the conflict itself and domestic abuse and killings are increasing, seeming 'almost normal'". In South Africa, the present is tainted by the past that sought to annihilate whole communities and subject them to total control. The feminisation of the country, as demonstrated in Coetzee's Disgrace, was a ploy akin to controlling the body of the woman. The protection provided and the impunity demonstrated by those in power, as illustrated in The Lost Boys of Bird Island for instance, illustrate the indignity the oppressed suffer in police states.

Denying the atrocities is the standard response of the state, however the scars left by the abuse tell the story. Of all the consequences of rape, pregnancy is perhaps the most devastating to women, the families and the community at large. Long before the child is born the woman has to decide whether to keep it or not. Such a decision is like a second violation as the woman would feel ashamed for even thinking of terminating the pregnancy, while the same time the innocent is a stark reminder of the violation. This confusion affects the survivor psychologically. Keeping the baby has its complications that would reverberate throughout the history of the community. The stigma and shame do not die with the product of rape. As Clifford (2008) states, "rape leaves a permanent reminder of war and of the enemy through the birth of a child, which places both the mother and child in continual victimization and isolation". "Rape", Thornhill \& Craig (2000: p. 7) argue, "reduces female reproductive success in several ways. For one thing, the victim may be injured. Moreover, if she becomes pregnant, she is deprived of her chance to choose the best father for her children". Children of rape too suffer untold trauma as they are often isolated by family and community. In some communities they are called names or even chased out as they remind the community of the enemy. Many blame themselves for the anguish of their mothers, and often become aggressors too owing to the anger they carry. Others pay the 
ultimate price, suicide, for a crime they didn't commit.

\section{Brutality of Entitlement in Aidoo's Changes}

Statistic South Africa 2000 reports that the incident of rape is likely to occur in the home of the victim or perpetrator (64\%). Although Changes is set in Ghana, it is not surprising then that the main character, Esi, is rape in her house by her first husband, Oko. What this shows is that the aggressor, in more cases than not, is known to the survivor and may be a spouse or benefactor. The violation in such spaces is an expression of cultural power relations, where the aggressor feels entitled to having his way with the survivor. This is consistent with Jewkes et al.'s (2010: p. 23) study which points out that "men indicated that rape most commonly stemmed from a sense of sexual entitlement ... it was often also a punishment directed against girlfriends", and in our case, wives. The "punishment" is sometimes deployed to fix the man's damaged masculinity, a point masterly illustrated in Aidoo's play Anowa. In the play Kofi is convinced that he can only be a real man if he manages to domesticate his hard-working wife, Anowa. Similarly, in Changes, Esi's violation by her husband demonstrates not only the constraints of married life, but also the namelessness of rape in married situations. Upon realising that she had been raped, it comes as a shock to Esi that her language or any other African language doesn't have an equivalence of "marital rape". And since a parallel phrase doesn't exist in her language, it follows then that marital rape is a foreign concept that doesn't obtain in her society. Concurring with this, Jewkes et al. (2010: p. 23) argue that "many women perceive that they are unable to legitimately refuse sex with a husband or boyfriend, to the extent that sexual coercion by an intimate partner is often regarded a 'not rape"', echoing David Lurie's characterisation of his violation of Melanie in Disgrace.

Marriage, as many commentators have noted, is a space of women domination in which their patience and faithfulness is expected, if not demanded. Esi is an independent, educated and ambitious careers woman. She is satisfied with the life she leads and even seems to believe that she can function in the marriage institution on her own terms. Oko though is not satisfied with his high-earning wife and wants to curtail her growing power through child birth. It doesn't take Esi long to realize that, despite his love for her, Oko is a patriarch at heart. Notwithstanding her confusion and disappointment, Oko expects her to play her role as a dutiful wife by, among other things producing children at the expense of her career. However, she chooses her freedom to a constricting marriage and divorces him because she appreciates that, as Muhomah suggests, with marriage comes responsibilities that make love a burden and not a delight that she envisaged. Until Esi divorces, she is not aware that her husband only lusts after her, especially when he observes her nakedness. In other words, to him she is a sex symbol and not someone to be loved. Oko goes through a number of sensations as he scrutinises her navel; such as rage at Esi's refusal to have another child, 
frustration that he is unlike his friends who apparently have more than one child and being provoked by Esi's body. He is aware that these sensations threaten their marriage and is determined to save it in the way a man should, sex. Sex is the language he prefers to deploy to save his marriage. In his heart of hearts, he believes that, as a man, having sex with his wife is by right his. Jewkes et al. (2010: p. 23) call this "accentuated gender hierarchy".

That Oko perceives the rape as a panacea for his marital woes is general misconception of men that they own a woman's body. As McKibbin et al. (2008: p. 88) points out, rape and sex in general are a strategy that at times are deployed to subdue a woman's aspirations for upward mobility. Procreation seems to be uppermost in men minds, if not by consent, then through coercion. According to McKibbin et al. (2008: p. 88) the would-be rapist may be more likely to target a highly fertile woman than a woman who is less fertile. In this regard, Oko is not simply driven by desire to have sex with Esi because like many men in patriarchal societies he believes he can have sex with his wife as and when he needs to. He rapes her because he wants children in order to stabilise their marriage and shore up his image in his community. Some studies show that fertile women who are raped are likely to fall pregnant even though more research still needs to be done to conclusively ascertain this assertion. Oko doesn't show any remorse for his behaviour, and long after the rape still believes he was only trying to save their marriage. Since rape is a conditional strategy, as McKibbin et al. (2008: p. 88) offer, Oko's strategy is to subdue Esi's flourishing career through childbearing. To Esi though, the violation is traumatic and means something totally different to what Oko has in mind.

That "something" though is unsayable, hence the silence that devours her inside. As she confesses at the beginning of the novel, silences sometimes have a way of screaming strange messages. Her realisation that she had been raped shudders her because she doesn't expect such violation in modern societies. She is shocked to realise that rape is normalized in marriage and accepted as part of the deal. In other words, in African societies a husband could never rape his wife since he is entitled to demanding it. The notion that there is no such thing as marital rape in African cultures affects her total being. Being unappreciative of their rights is at the centre of the female survivors' silence. Esi dreads being seen in public or be heard speaking to anyone, even her family-this is similar to what happens to Marguerite in I Know Why the Caged Bird Sings. Her world collapses, resulting in her decision find refuge in divorce-again opting for a foreign concept because in African cultures divorce is shunned. Hence she becomes a target of ridicule for leaving a kind-hearted man for a life of loneliness and isolation. Even after the rape, Oko believes that he had done all he could do to get her to see that he loves her. In fact, he had "jumped on her" because he loves her and that raping her has been part of his decision to give the relationship a second chance. Everyone seems to believe that she not only instigated the violation, but also deserved what happened to her. Her grandmother's warning 
is telling here when she cautions her thus: Love? ... Love? ... Love is not safe my Lady Silk, love is dangerous. It is deceitfully sweet like the wine from a fresh palm tree at dawn. Love is fine for singing about and love songs are good listening to, sometimes dancing to. But when we need to count on human strength, and when we need to count pennies for food for our stomachs and clothes for our backs, love is nothing ... the last man any woman should think of marrying is the man she loves.

Despite this warning and in accordance with her friend Okopuya's pronouncement that, no one can stay alone forever, Esi falls in love with Ali because. Opokuya points out, "it is easy to see that our societies have had no patience with the unmarried woman. People thought her single status was an insult to the glorious manhood of our men. So they put as much pressure as possible on her ... until she gave in and married or remarried, or went back to her former husband ... and of course if nothing cured her they ostracised her and drove her crazy ... and then soon enough, she died of shame, loneliness and heartbreak". Although Esi dearly loves Ali, she is unaware that he cynically regards her divorce as "nicely mad". Clearly, Ali too doesn't believe marital rape exists and is a gross violation of her rights, that is why he views her as a gift from Allah. As a gift he is entitled to do with her as he wishes. In fact, Ali questions Esi's decision in a rather pointed manner when he asks, why have we got so used to describing our cultural dynamics with the condemnatory tone of our masters? To a large extent he justifies the "rape", and closes ranks with his adversary Oko in the process. It is not surprising, therefore, when Esi's second marriage becomes unbearable and disastrous. It is not necessarily finding herself in a polygamous marriage that destroys her self-worth, but her realisation that this is a man's world and the society accepts it as such. The rape incident then unleashes a ripple effect that leaves the woman character vulnerable, defeated and powerless. Through Esi's experiences, it becomes clear that women are sex toys whose lives revolve around the whims of men. As is the case with Esi, once married, women are used to satisfy men's sexual appetites, and, often than not, marital rape is used as a weapon of domination and power. Violators use marital rape as a means to assert themselves, without considering the psychological effects of their actions on the women they victimise. Sex, in this instance, is utilised to affirm the dominance of the man; it reflects and affirms the power of patriarchy.

\section{The Rape of the Innocent in Angelou's I Know Why the Caged Bird Sings}

Ali's characterisation of Esi's divorce as "nicely mad" demonstrates his apathy and insensitivity and by extension, men's lack of understanding of the impact of rape on women. As contended above, sex in marriage is the prerogative of the husband. The woman is not expected to deny him of this God-given right, hence Ali sees Esi as "a gift from Allah". The trauma and psychological damage Esi goes through are immeasurable and are compounded by her silence which is 
misconstrued as her acceptance of the situation. But, as alluded to above, silence is the language of the survivors. Such silences are even worse where children are concerned since they lack the necessary vocabulary for their torment. Because of the silence the violators are often encouraged and emboldened since their actions go unnoticed, as is the case in Maya Angelou's I Know Why the Caged Bird Sings. Coupled with their voicelessness, it is disheartening to note that child victims, as Statistics South Africa 2000 says, are often excluded from reports. However, they do acknowledge that the underreporting doesn't mean children are immune to attacks. In fact, many newspaper reports do highlight the violation of children by older men, especially men related to them. Perpetrators, it would seem, understand the vulnerability of the children, hence they would develop elaborate plans to hypnotize the victim with fear, and force her acceptance of the status quo.

As alluded to earlier, there are different views of rape motivation. One popular view of rape motivation, as Hamilton \& Yeew (1990: p. 111) avers, hold that "rape is a means by which men express hostility or anger towards women". In the case of children though, especially step-daughters, this view doesn't often hold since the abuser is neither hostile nor angry against the child but downright evil. Critically, in their research Jewkes et al. (2010: p. 27) mention that men also linked "child rapes to opportunity, as half the men perpetrating young child rape said the girl wouldn't tell". Their seeming affectionate behaviours ensure that the victim accepts their victimhood as normal and inevitable. Step-daughters don't only lack the necessary language to express their inner thoughts and feelings; they also do not have the necessary support system. The perpetrator knows this and uses it to leverage his advantage over the survivor. Hamilton \& Yeew (1990: p. 112) note "that there is a widely held suggestion that rapists, or men identified as usually likely to rape, are characterized by the belief that rape is not aversive to women-that, in fact, women desire and enjoy it". The infamous rape allegation of Fezekile "Khwezi" Khuzwayo in 2017 in South Africa is perhaps a classical example of such beliefs. Court testimonies related how she asked for it for wearing a kanga (a wrap-around) in the perpetrator's house and how she waited until the morning and asked for taxi fare home from the perpetrator. Such allegations suggest her being an active participant in her victimisation. In this regard, perpetrators are of the view that they are right when they lack appreciation of the hurt they cause. As Hamilton \& Yeew (1990) further point out, the perpetrators lack of knowledge or apathy about the real feeling of the victim perpetuates this myth because studies show that if they knew they wouldn't have the propensity to rape. Rape has psychological and behavioural consequences. While the lack of knowledge and apathy do not necessarily absolve the violator of his wrongdoing, Hamilton's point is key in the fight against rape. In this regard, if men were to understand the enormity of the psychological damage they cause the survivor, their propensity to rape would diminish. To this end, it may be more useful to ask not what is the motivation for rape but rather what is the 
most prevalent motivation. Distinguishing between rape as a means to gain sexual gratification and rape to hurt may, as Hamilton suggests, help in changing the mind-set around the scourge.

In I Know Why the Caged Bird Sings, Mr Freeman has no reason to hate or be angry against Marguerite. From the beginning it is clear that all he desires is to have sex with her; hence he takes time grooming her until the rape incident. Many rapists don't act impulsively, they plan and scheme their actions so meticulously that the survivor often realises much later that she had been duped. In Disgrace, for instance, David Lurie sweet-talks Melanie into falling into his trap. Over coffee with a shot of whisky he ensnares her like the professional he is: You are very lovely, he says. I'm going to invite you to do something reckless. He touches her again. Stay. Spend the night with me. His matter-of-fact answer to Melanie's query as to why she should spend the night with him demonstrates his low regard of her and women in general. He says; Why? Because a woman's beauty does not belong to her alone. It is part of the bounty she brings into the world. She has a duty to share it. Such is the burden of women. More often than not the survivor blames herself after the abuse, thereby cushioning the perpetrator of the act. In Marguerite's case, her mother's seeming trust in Mr Freeman is enough to make the eight-year-old believe that the latter loves her as a father should. At eight, she is not matured enough to properly read and understand adults' behaviour. In her naiveté, grownups are there to love and protect the young ones. It is in this spirit she accedes to Mr Freeman's entreaties that, "Just stay right here, Ritie, I ain't gonna hurt you" as he tentatively encroaches into her psyche.

Their first physical encounter not only gives Mr Freeman hope that his intentions would be realised, but also entangle Marguerite into the conspiracy of silence. She learns to trust Mr Freeman wholeheartedly because for quite some time she and her brother, Bailey, had been deprived of a father figure. Mr Freeman is acutely aware of her emotional dependence in him, hence it is easy for him to make her self-blame instead of her seeing the violation for what it is. When she is accused of peeing on the sheets, for instance, she takes full blame in order to maintain stability and a sense of belonging. Her sense of loss and the threat against her brother hurts and confuse her immensely. Hence, she blames herself. Secretly, she determines herself to protect him by keeping the secret between herself and Mr. Freeman to herself.

As demonstrated in the novel, rapists are masters of emotional blackmail. In their research, Walker et al. (2005: p. 73) capture this well when they recount what the victims recall of the perpetrators words during the rape. They relate a victim who was told to be a good boy and he would enjoy it, while the other victim was told how physically attractive he was and also informed how many orgasms the perpetrator had and how much he, the victim, enjoyed it. This obtains across genders. Hence, even though Marguerite is violated, she cannot find any reason to dislike Mr Freeman except accepting the fact that she doesn't under- 
stand him. When he abuses her the second time, the result is the same-silence. It would seem Mr Freeman normalises their relationship, hence she is confused when he ignores her for months after that. Her longing for affirmation and love blinds her to the wrongdoing, leading to the ultimate betrayal of trust when $\mathrm{Mr}$ Freeman finally penetrates her.

This is opportunistic rape both because of the seclusion of the house where it happens, and the knowledge that the survivor will not talk. The context in which the act takes place is critical here. As Thornhill \& Craig (2000: p. 4) maintain, men could have evolved to practice rape when the costs seem low-when, for instance, a woman is alone and unprotected and thus retaliation seems unlikely, or when they have physical control over a woman and so cannot be injured by her. After the rape Marguerite can only say that the act of rape on an eight-year-old body is a matter of the needle giving because the camel can't. The child gives, because the body can, and the mind of the violator cannot. The damaged caused physically count for nothing compared to her psychological trauma. She acts normal as instructed by her tormentor and the world only observes her physical being and construes what it sees as a common ailment-measles. Only Mr Freeman and she know the extent and nature of her predicament, but that knowledge is smothered in silence. Their conspiracy of silence ensures that the perpetrator maintains his dominance while the survivor is emotionally tortured and paralyzed. It is for this reason that she says it seems my head had gone away and pure air had replaced it on my shoulders. Flashbacks of the incident recur, making her feel like dying. Everyone makes light of the situation she finds herself in with the nurses even suggesting that the worst is over for her as though the rape was just a rite of passage whose memory would soon fade. Throughout her torment she uses silence as a retreat, as a place of refuge even though that too is misconstrued as insolence by her family. No one in the family empathises with her as if sexual violation is a passing phase. Little do they know that she has suffered a lifelong damage which may affect her love relationships later. In turn, that would impact reproduction which is an insurance of survival for any society. Hence I argue, rape is not an individual's burden but that of the society at large.

\section{Hostility-Driven Aggression in Duiker's The Quiet Violence of Dreams}

The discussion so far has dealt with female survivors, where the violator feels entitled through marriage or relational connections to the survivor. In both instances the perpetrator is driven a desire to control, have sex with and exercise power over them, without any consideration for the lifelong trauma caused. One of the main achievements of South Africa's attainment of independence in 1994 is the promotion of individual rights. With the human rights, individuals increasingly felt empowered to disclose their sexual orientation. Intolerance grew in direct proportion with the disclosures leading to the sexual assault and some- 
times murder of lesbians and gays. Homophobia, then, has become one of the motivations for sexual violence as Duiker's The Quiet Violence of Dreams aptly illustrates. Victims of homophobia are left with deep scars which manifest in self-doubt, self-blame and confusion. This is what Hamilton \& Yeew (1990: p. 112) refer to as hostility driven rape, where violence is in itself the goal the violator seeks to achieve. In hostility driven rapes, the inflicted pain tends to anger the aggressor; resulting in more brutality.

Two incidents illustrate this in the novel where in the first the young Tshepo is gang raped. When the intruders gain access to his home and tie up his parents, to Tshepo it looks just like a normal break-in witnessed almost every day in Cape Town. However, reality dawns on him when his mother, his pillar, is raped in his presence. His world is shattered. Later he recalls hearing two gun shots fired and believes that both her parents had been killed. When they turn to him and sodomise him, his life as he knew it ends. Even his father's mysterious escape from physical harm is little solace to him. In fact, he finds it hard to understand why his father would save them from the ordeal. From then on he lives a life of drugs and self-doubt. His damaged soul is compounded when he learns that his father has collected insurance money after the demise of his mother. He physically and emotionally cut ties with him, resulting in his roaming around Cape Town streets aimlessly, ending with a frustrating stint at a mental institution.

Perhaps it is his sexual orientation that confuses him the most after the rape, as a result he becomes meditative, silent and reclusive. He secretly works at a male massage agency, excusing this as easy money. Secretly though, he knows he is attracted to males and feels his dealing with them completes the puzzle of his sexual life. He is attracted to his flatmate, Chris, to fulfil his sexual desire. Instead of complimenting the attention, Chris and his friends gang rape and rob him, ostensible angered that he is behind in rent payment. This vastly confuses Tshepo, resulting in his deep depression and anger. His reaction to the rape is not exclusive to him, but is the way male survivors often react to rape. Most of the male rapes are driven by hate and anger, in some cases due to pure homophobia. The hostility-driven aggression demonstrated, pushes him over the edge, especially because he doted on Chris. Since Chris is perfect in his eyes, he begins to blame himself and ascribes the rape to something that he may have done. $\mathrm{He}$ believes he deserves the treatment.

Male rapes and the associated damage on the survivors are often neglected in research According to du Toit (2014: p. 101), "we do not have proper record of male rape victim numbers. If we have a profile similar to the United States in this respect, male victims should make up about 7 percent of all rape victims, and male perpetrators would be more than 99 percent of all perpetrators". As Govinden suggests, literature sometimes obsesses about race issues at the expense of rape victims. The survivor too seems reluctant to report the violations. Internal as well as external factors may influence such a reaction. Internal factors 
include low self-esteem and guilt, while external factors may be occasioned by the fear of stigmatization and isolation. The survivor often suffers the ignominy of being made fun of, and in some cases falling prey to other rapists who want to "correct" him. The only way out of the dilemma is often suicide. In rare cases the survivor may decide to revenge on the perpetrator by committing a murder. As demonstrated in Changes, most violators are known to the survivor and gay men are the most vulnerable because they are often in the periphery of their communities. Walker et al. (2005: p. 69) point out that "long-effects of male rape include anxiety, depression, increased loss of self-image, emotional distancing, self-blame and self-harming behavior".

Rape results in the survivor self-doubting his manhood, something that affects his self-image and self-identity. More often than not the survivor begins to question his sexual orientation; hence a majority of heterosexual survivors seek out homosexual contact after the rape. In extreme cases though, the reverse is true; the survivor is revolted by all gay men. Their revulsion at the act and the homosexuals may sometimes result in gang rape, physical harm or even murder. Some survivors' sexual relation with the opposite sex comes to a halt as any sex encounter becomes a torture to them, a reminder of the unprovoked emasculation. In most cases the rape incident affects their identities as lovers and fathers as these integral self-identity components are undermined by their experiences.

Tragically, as pointed out, male survivors hardly report the violations for fear of secondary victimisation caused by the insensitivity of the society to male rape. Research such as that of Walker et al. (2005: p. 74) reveal that sometimes the victims are told that they deserved or asked for what happened to them once they report. The low believability of the male victim is not only at the level of civilians, officials who are supposed to understand what the victim goes through are often in the frontlines of the second victimization. In health facilities, for instance, many survivors only report physical injuries they may have and hide the aspect of rape. This unfortunately opens them up to STI risks since they end up not being treated for them. With the police too, the survivors are reluctant to open up because the treatment they often receive is far more severe compared to the rape itself. The survivors are subjected to taunts and labelling which deepen their psychological damage. This reaction points both to insensitivity and inadequate training in health institutions and police stations. Homophobia too plays a critical role in the way officials react to a male survivor. Instead of empathising with the survivor, they blame him for not being man enough. Therefore, instead of justice, the survivor is humiliated and denigrated. In Tshepo's case, aimless roaming the streets becomes his sole occupation.

\section{Conclusion}

It is evident from the discussion above that the understanding of rape and its consequences on the survivor still need comprehensive study. Obsessively dealing with rape from a race and gender perspective is inadequate; therefore more 
creative and innovative ways should be developed to fully address the scourge. In order to find solutions to the rape problem, rape narratives should embrace the global character of rape and the lasting effects it has on the survivors. Even though it is widely acknowledged that rape mainly affects women, child and male rape thrive below the surface. Research in these two sections of the society needs more effort and focuses because, just like the violation of women, the psychological scars left are deep and affect family, community and the nation. Countries where rape has been used as tool of war are forever stained by the violation especially because in many instances the violation is normalised through lack of accountability. While there are two broad reasons why men rape, namely to have sex or to hurt, understanding that there are different types of rapists would help in coming up with practical, workable solutions. Unless there are sensitivity and compassion demonstrated for rape survivors, they would suffer in silence thereby further exacerbating the rape culture. Legal intervention is critical. However, acting after the fact is counterproductive and only serves to entrench the culture of rape. Well-considered and researched programs should deter the would-be rapist. Such programs should make would-be rapists aware of the psychological impact of rape as that may help them rethink their intentions. As the texts dealing with demonstration, rape is a global issue whose impact destabilizes whole nations; therefore reducing the challenge to individuals would be a gross avoidance of a far larger unremitting challenge.

\section{Conflicts of Interest}

The author declares no conflicts of interest regarding the publication of this paper.

\section{References}

Aidoo, A. (1991). Changes. Oxford: Heinemann.

Angelou, M. (1984). I Know Why the Caged Bird Sings. London: Virago.

Caryl, C. (2017). Rape Is Still Being Used as a Weapon of War. Right Now. Today. DemocraticPost.

https://www.washingtonpost.com/news/democracy-post/wp/2017/11/21/rape-is-still-b eing-used-as-a-weapon-of-war-right-now-today/

Clifford, C. (2008). Rape as a Weapon of War and Its Long-Term Effects on Victims and Society. Washington DC: Stop Modern Slavery.

Coetzee, J. M. (2000). Disgrace. London: Vintage.

du Toit, L. (2014). Shifting Meanings of Postconflict Sexual Violence in South Africa. Journal of Women in Culture and Society, 40, 101-123. https://doi.org/10.1086/676895

Duiker, K. S. (2001). The Quiet Violence of Dreams. Cape Town: Kwela Books.

Govinden, B. (2013). State of Peril-Race and Rape in South African Literature by Lucy Valerie Graham. Agenda, 27, 151-154. https://doi.org/10.1080/10130950.2013.778625

Hamilton, M., \& Yee, J. (1990). Rape Knowledge and Propensity to Rape. Journal of Research in Personality, 24, 111-122. https://doi.org/10.1016/0092-6566(90)90010-4

Jewkes, R. et al. (2010). Why, When and How Men Rape: Understanding Rape Perpetra- 
tion in South Africa. South African Crime Quarterly, 34, 23-31.

McCulloch, J. (2000). Black Peril, White Virtue: Sexual Crime in Southern Rhodesia. Bloomington, IN: Indiana University Press.

McKibbin, W. F. et al. (2008). Why Do Men Rape? An Evolutionary Psychology Perspective. Review of General Psychology, 12, 86-97. https://doi.org/10.1037/1089-2680.12.1.86

Mda, Z. (2002). The Madonna of Excelsior. Oxford: Oxford University Press.

Minnie, M., \& Steyn, C. (2018). The Lost Boys of Bird Island. Cape Town: Tafelberg.

Noelle-Neumann (1974). The Spiral of Silence Theory of Public Opinion. Journal of Communication, 24, 43-51.

Thornhill, R., \& Craig, P. (2000). Why Men Rape? New Yolk Academy of Sciences, 40, 30-36. https://doi.org/10.1002/j.2326-1951.2000.tb03465.x

Tlhabi, R. (2017). Khwezi. Jeppestown: Jonathan Ball.

van der Westhuizen, C. (2017). Sitting Pretty: White Afrikaans Women in Postapartheid South Africa. Scottsville: University of South Africa Press.

Walker, J. et al. (2005). Effects of Rape on Men: A Descriptive Analysis. Archives of Sexual Behavior, 34, 69-80. https://doi.org/10.1007/s10508-005-1001-0 